\title{
MENINGKATKAN EKSISTENSI DAN PELESTARIAN BATIK DI ERA MODERN
}

\author{
Shofiatul Jannah'1, Iin Indrawati', Hesti Dwi Rahayu'1, Sehat Marwan'2, Muhammad \\ Kholid Najmuddin ${ }^{1}$, M. Thohar Mufaiz ${ }^{2}$, Andik Dewantoro ${ }^{3}$, Kisah Irawan Mega ${ }^{2}$, M. \\ Safari Almukri , Arie Yudhistira Suhermanto4, Diyan Zaidah Muhimmatul Hidayah', \\ Meryna Rachmi Putri ${ }^{3}$ \\ ${ }^{1}$ Fakultas Agama Islam, Universitas Islam Malang \\ ${ }^{2}$ Fakultas Keguruan dan Ilmu Pendidikan, Universitas Islam Malang \\ ${ }^{3}$ Fakultas Ekonomi dan Bisnis, Universitas Islam Malang \\ ${ }^{4}$ Fakultas Pertanian, Universitas Islam Malang \\ Korespondensi email: shofiasamsularifin@gmail.com
}

\begin{abstract}
ABSTRAK
Batik adalah suatu hasil karya yang tidak asing lagi bagi masyarakat Indonesia.Di berbagai wilayah Indonesia banyak ditemui daerah-daerah pengrajin batik. Setiap daerah pembatikan mempunyai keunikan dan kekhasan tersendiri, baik dalam ragam hias maupun tata warnanya. Seiring perkembangan zaman, menurut Sudijono (2006), budaya batik tulis semakin terkikis karena semakin murahnya batik yang dating dari luar negeri dan semakin berkembangnya batik cetak yang bisa memenuhi kebutuhan masyarakat akan kebutuhan batik secara cepat. Tulisan ini bertujuan Untuk mengetahui gambaran Kelompok Ibu-ibu PKK di Desa Bringin, Kecamatan Wajak, Kabupaten Malang, peran, kendala yang dihadapi, dan upaya mengatasi kendala yang dihadapi pada Kelompok Batik Ibu-ibu PKK, Desa Bringin, Kecamatan Wajak, Kabupaten Malang. Kelompok batik Ibu-ibu PKK jika tidak ada permintaan ataupun ada event maka pengrajin tidak akan berproduksi. Program KKN adalah program Kuliah Kerja Nyata dimana mahasiswa diharapkan mampu mengimplementasikan ilmu yang diperoleh secara teoritis menjadi praktis dalam bentuk pengabdian dan pendampingan langsung terhadap masyarakat. dengan adanya potensi yang dimilki oleh Ibu-ibu PKK di Desa Brigin, maka program kerja yang disusun adalah Pelestarian Batik Era Modern untuk memecahkan masalah tersebut. Diharapkan mampu membantu para Ibu-Ibu PKK untuk memperkenalkan produknya dalam skala yang luas serta mengembangkan Batik sesuai dengan Era Modernisasi saat ini. Hal ini merupakan suatu upaya untuk memperkenalkan kepada masyarakat bahwa Batik merupakan ikon asli Indonesia yang harus dilestarikan.
\end{abstract}

Kata Kunci: eksistensi; pelestarian; era modern.

\section{PENDAHULUAN}

Batik adalah suatu hasil karya yang tidak asing lagi bagi masyarakat Indonesia.Di berbagai wilayah Indonesia banyak ditemui daerah-daerah pengrajin batik. Setiap daerah pembatikan mempunyai keunikan dan kekhasan tersendiri, baik dalam ragam hias maupun tata warnanya (Masiswo, 2013) (Resticka et al., 2017). Seiring perkembangan zaman, menurut Marzuqi et al. (2015), budaya batik tulis semakin terkikis karena semakin murahnya batik yang dating dari luar negeri dan semakin berkembangnya batik cetak yang bisa memenuhi kebutuhan masyarakat akan kebutuhan batik secara cepat. Batik berasal dari bahasa jawa " mbatik", yaitu mbat yang merupakan kependekan dari ngembat atau 
melontarkan dan tik yang merupakan kependekan dari titik sehingga batik diartikan sebagai melemparkan titik berkali-kali dalam selembar kain (Nursaid \& Armawi, 2016). Setiap daerah tentu memiliki kekhasan batiknya masing-masing, begitu pula dengan batik tulis di Desa Bringin (Ariana \& Pamungkas, 2015). Tulisan ini bertujuan Untuk mengetahui gambaran Kelompok Ibu-ibu PKK di Desa Bringin, Kecamatan Wajak, Kabupaten Malang. peran, kendala yang dihadapi, dan upaya mengatasi kendala yang dihadapi pada Kelompok Batik Ibu-ibu PKK, Desa Bringin, Kecamatan Wajak, Kabupaten Malang. Kelompok batik Ibu-ibu PKK jika tidak ada permintaan ataupun ada event maka pengrajin tidak akan berproduksi. Jika tidak ada produksi maka tidak ada orang yang bekerja di batik. Jika tidak ada yang bekerja maka mereka tidak akan sejahtera. Jika tidak sejahtera dengan usaha batik maka ia akan menghentikan usaha batiknya dan beralih ke bidang lain (Danial et al., 2019). Jika tidak ada yang bekerja di sektor batik maka batik akan punah, padahal batik merupakan warisan budaya yang tak ternilai harganya. Oleh karena itu dibutuhkan intervensi pasar guna memperbanyak permintaan akan batik sehingga pengrajin sejahtera. Namun, jika pasar terbuka lebar, tetapi tidak ada produsen batik dapat menimbulkan masalah baru karena perlu mendatangkan barang dari daerah lain. Oleh karena itu, selain membuka pasar diperlukan upaya peningkatan ketrampilan sumber daya manusia di Desa Bringin dalam usaha batik sehingga tersedia tenaga kerja dan calon pengusaha-pengusaha baru.

Program KKN adalah program Kuliah Kerja Nyata dimana mahasiswa diharapkan mampu mengimplementasikan ilmu yang diperoleh secara teoritis menjadi praktis, dalam bentuk pengabdian dan pendampingan langsung terhadap masyarakat, di samping pengabdian dan penelitian yang dilakukan sebagai usaha pendalaman ilmu yang diperoleh sebelumnya. Kuliah Kerja Nyata (KKN) juga memiliki kemampuan dalam mengatasi berbagai macam problematika yang terjadi di masyarakat sebagai media untuk belajar membangun hubungan di dalam komunitas masyarakat (Syardiansah, 2019). Hal ini merupakan tujuan utama yang akan dihadapi pasca menyelesaikan study, dengan adanya problem yang dihadapi oleh Ibu-ibu PKK di Desa Bringin, maka program kerja yang disusun adalah meningkatkan eksistensi dan pelestarian batik era modern yang memiliki potensi penembangan yang sangat prospektif (Nasution et al., 2019).

Untuk mengatasi berbagai prolematika yang ada, sehingga produk yang dihasilkan dari Desa Bringin dapat dikenal dengan motif dan coraknya yang luar biasa, sehingga dapat dikenal diseluruh tempat di Indonesia, selain membuka pasar diperlukan upaya peningkatan ketrampilan sumber daya manusia di Desa Bringin dalam usaha batik sehingga tersedia tenaga kerja.

Manfaat diadakanya pelestarian adalah (1) Memberikan pemahaman bagi masyarakat umum khususnya Desa Bringin Kecamatan Wajak Kabupaten Malang tentang eksistensi batik tulis di era modern (2) Memberikan Informasi kepada masyarakat bahwa kita semua prelakukan upaya untuk melestarikan batik dengan cara mengembangkan motif dan coraknya; (3) kelompok batik sebagai jembatan kesejahteraan. Produk batik dari Ibuibu PKK menggunakan bahan kain primisima atau prima mesres dengan pewarnaan alami maupun sintetis; dan (4) kelompok batik tulis Ibu-ibu PKK di Desa Bringin sebagai obyek wisata alternatif dan tempat pendidikan tentang batik tulis.

\section{METODE}

Untuk mencapai tujuan yang diharapkan, program KKN di Desa Bringin, dilakukan dengan belajar bersama Ibu-ibu PKK melalui peningkatan eksitensi dan pelestarian batik di era modern.Selain itu kegiatan yang dilakukan dari program KKN di Desa Bringin untuk meningkatkan produksi batik tulis dengan berbagai corak sesuai dengan perkembangan 
fashion batik yang saat ini semakin beraneka ragam dipasaran.Dengan begitu kelompok dari Ibu-ibu PKK lebih kreativitas dalam pembutan batik tulis di Desa Bringin, hal ini juga akan berpengaruh terhadap pendapatan yang diperoleh.

Ringkasan metode pelaksanaan beserta jam kerja efektif mahasiswa (KKN) tersaji dalam tabel 1 sebagai berikut:

Tabel 1. Metode Pelaksanaan

\begin{tabular}{|c|c|c|c|c|}
\hline No & Metode & Kegiatan & Waktu & $\begin{array}{c}\text { Jumlah mahasiswa } \\
\text { yang terlibat }\end{array}$ \\
\hline 1 & Sosialisasi & $\begin{array}{l}\text { Menyampaikan maksud dan } \\
\text { tujuan dari kegiatan } \\
\text { pelestarian batik }\end{array}$ & $\begin{array}{l}\text { 10:00 WIB } \\
09 / 02 / 2020\end{array}$ & 6 mahasiswa \\
\hline 2 & Sosialisasi & $\begin{array}{l}\text { Menyampaikan pengetahuan } \\
\text { tentang modernisasi Batik }\end{array}$ & $\begin{array}{l}14: 00 \text { WIB } \\
16 / 02 / 2020\end{array}$ & $\begin{array}{l}6 \text { mahasiswa dari } \\
\text { kelompok } 5\end{array}$ \\
\hline
\end{tabular}

\section{HASIL DAN PEMBAHASAN}

Dalam rangka meningkatkan eksistensi dan pelestarian batik di era modern, perlu adanya sosialisasi kepada masyarakat khususnya Ibu-ibu PKK desa Bringin untuk bisa mengembangkan motif dan corak batik lebih fleksibel menyesuaikan perkembangan zamanya. Adaun proses pembuatn batik yang dlakukan adalah sebagai berikut:

1. Pengkhetelan

Batik dibuat diatas kain mori. Kain mori adalah kain tenun yang berwarna putih yang biasa digunakan sebagai kain untuk membatik.

2. Menyorek

Ketika membuat batik, tentunya seorang pembatik harus memikirkan gambar apa yang harus ia lukis diatas kain mori. Seperti menuangkan insprasi kedalam bentuk gambarnya dikertas terlebih dahulu, biasanya menggunakan bolpoin atau pensil.

3. Nyanting

Nyanting merupakn proses menapikasikan lilin malam yang akan dibubuhkan persis pada gambar yang sudah ditulis dikain mori.

4. Nembok

Nembok merupakan bagian yang lain yang tidak digambar dengan pensil, tapi ingin diberi warna lain. Bagian ini harus ditembok dengan lilin malam biar bagian tersebut tidak berwarna sama dengan warna dasar.

5. Nyelup

Nyelup merupakan proses pewarnaan kain batik. Yang dimaksud dengan mewarnai disini adalah memberikan warna dasar kepada kain. Setiap daerah memiliki proses pencelupan sendiri-sendiri, Bahkan pembatik disuatu daerah yang sama bisa memiliki proses pencelupan yang sama dan juga berbeda pula.

Demkian Proses yang dilakukan selama membatik, Ibu-ibu PKK desa Bringin memiliki potensi yang luar biasa jika terus dikembangkan. Dalam memperkenalkan produknya Ibu-ibu PKK masih mengandalkan pemasaran via offline, dimana persaingan perdagangan sudah merambat pada dunia online. Dengan adanya permasalahan tersebut mahasiswa KKN Kelompok 5, berusaha mendorong Ibu-ibu PKK untuk mengunakan stategi lewat Media sosial seperti Facebook dan lain sebagainya.

\section{KESIMPULAN}

Berdasarkan penjelasan tersebut di atas, maka dapat ditarik simpulan sebagai berikut Pertama Kelompok Batik Ibu-ibu PKK, Desa Bringin, Kecamatan Wajak, Kabupaten Malang. memiliki peran dalam mencapai ketahanan ekonomi keluarga. Peran yang dicapai yaitu Kelompok batik tulis di Ibu-ibu PKK sebagai obyek wisata alternatif dan tempat 
pendidikan serta kelompok batik sebagai jembatan kesejahteraan. Pemerintah daerah hendaknya dapat menyediakan akses transportasi dan akses jalan yang sesuai dengan standar sebagai infrastruktur daerah wisata, sehingga dapat dijangkau oleh wisatawan. Kedua, mengingat pangsa pasar yang cukup besar di Desa Bringin, Kecamatan Wajak,hendaknya dilakukan koordinasi antara pemerintah daerah dan pihak swasta dalam pengadaan jaringan internet dan telekomunikasi, sehingga produk batik Desa Bringin, Kecamatan Wajak dapat dipasarkan melalui jaringan internet dan telekomunikasi tersebut.

Program KKN dalam upaya meningkatkan eksistensi dan pelestarian batik era modern yang telah berjalan dengan baik, dimana tingkat partisipasi Ibu-ibu PKK untuk dapat mengikuti sosialisasi dan menumbuhkan rasa modernisasi dalam motif dan coraknya, serta pengenalan dalam bentuk digital sangat interaktif. Dengan diakannya kegiatan sosialisasi oleh kelompok 5 ini masyarakat umumnya dapat meghargai dan melestaikan batik sebagai ikon asli budaya Indonesia.

\section{UCAPAN TERIMA KASIH}

Penulis sampaikan terima kasih kepada perangkat Desa Bringin yang telah menerima kami dengan baik dan seluruh masyarakat desa Bringin yang telah berpartisipasi dan mendukung kami.

\section{DAFTAR RUJUKAN}

Ariana, N. E. R., \& Pamungkas, Y. H. (2015). Perkembangan Motif Batik Suminar Sebagai Upaya Membangun Identitas Daerah Kediri Tahun 1992-2004. AVATARA, E-Journal $\begin{array}{lll}\text { Pendidikan Sejarah, 310-325. } & \text { 310 }\end{array}$ https://jurnalmahasiswa.unesa.ac.id/index.php/avatara/article/view/12500

Danial, A., Darusman, Y., Mustakim, \& Herwina, W. (2019). Model Pemberdayaan Masyarakat Melalui Pola Magang Tradisional Dalam Upaya Peningkatan Wirausaha Masyarakat. Jurnal Inovasi Hasil Pengabdian Masyarakat (JIPEMAS), 2(1), 31-48. https://doi.org/10.33474/jipemas.v2i1.2182

Marzuqi, A., Fianto, A. Y. A., \& Hidayat, W. (2015). Penciptaan Motif Batik Sebagai Ikon Kabupaten Lumajang. Jurnal Art Nouveau, 4(1), 27-38. https://jurnal.dinamika.ac.id/index.php/ArtNouveau/article/view/754/0

Masiswo. (2013). Analisis Ikonografis Batik Motif Sidomukti Ukel Salem Kabupaten Brebes. Dinamika Kerajinan Dan Batik, 30(1), 31-44. https://doi.org/http://dx.doi.org/10.22322/dkb.v30i1.950.g813

Nasution, D. A. D., Dwilita, H., \& Arnita, V. (2019). Pengembangan Kewirausahaan Di SMA Negeri 1 Sunggal Kabupaten Deli Serdang Melalui Kegiatan Pelatihan Akuntansi. Jurnal Inovasi Hasil Pengabdian Masyarakat (JIPEMAS), 2(2), 110-119. https://doi.org/10.33474/jipemas.v2i2.2714

Nursaid, A., \& Armawi, A. (2016). Peran Kelompok Batik Tulis Giriloyo Dalam Mendukung Ketahanan Ekonomi Keluarga (Studi Di Dusun Giriloyo , Desa Wukirsari , Kecamatan Imogiri , Kabupaten Bantul, Daerah Istimewa Yogayakarta). Jurnal Ketahanan Nasional, 22(2), 217-236. https://doi.org/10.22146/jkn.12507

Resticka, G. A., Nurdianto, E., \& Haryanti, S. N. (2017). Inventarisasi Sistem Pengetahuan Teknologi Perbatikan Dalam Masyarakat Banyumas. Jurnal Lingua Idea, 8(2), 1-13. https://doi.org/10.20884/1.jli.2017.8.2.253

Syardiansah. (2019). Peranan Kuliah Kerja Nyata Sebagai Bagian Dari Pengembangan Kompetensi Mahasiswa (Studi Kasus Mahasiswa Universitas Samudra KKN Tahun 2017). Jurnal Ilmiah Manajemen UPB, 7(1), 57-68. https://doi.org/10.33884/jimupb.v7i1.915 